Vol. 1 No. 2 Desember 2021, e-ISSN : 2807-8667| p-ISSN : 2807-8837

\title{
PENERAPAN MODEL PEMBELAJARAN KOOPERATIF TIPE STUDENT TEAM ACHIEVEMENT DIVISIONS UNTUK MENINGKATKAN HASIL BELAJAR FIKIH SISWA KELAS VII MTS NEGERI LUWU UTARA KAB LUWU UTARA
}

\author{
RAMLAH \\ MTs Negeri Luwu Utara \\ Email:ramlahmading@gmail.com
}

\begin{abstract}
ABSTRAK
Penelitian ini dilatar-belakangi oleh pentingnya guru dalam memilih model pembelajaran yang tepat, agar pembelajaran itu sebanyak mungkin melibatkan siswa secara aktif, sehingga siswa dapat membangun pengetahuannya sendiri dalam sebuah pembelajaran yang menyenangkan yang berujung pada peningkatan hasil belajar. Tujuan utama penelitan ini adalah untuk mengetahui apakah dengan menerapkan model pembelajaran kooperatif tipe Student Team Achievement Divisions (STAD) dapat meningkatkan hasil belajar Fikih siswa kelas VII MTs Negeri Luwu Utara. Penelitian ini dilaksanakan di kelas VII MTs Negeri Luwu Utara yang dimulai pada pekan ke II bulan September sampai dengan pekan ke 1 Oktober 2020 (semester I) . Jumlah siswa yang terlibat sebanyak 69 orang, yang dibagi dalam 10 kelompok kerja. Observasi dilaksanakan selama dua siklus, dimana masing-masing siklus terdiri atas tahap persiapan (perencanaan), pelaksanaan tindakan, observasi dan evaluasi, refleksi, dan revisi tindakan. Analisis data dilakukan secara deskriptif, dengan menampilkannya dalam bentuk tabel, histogram dan dilengkapi dengan perhitungan persentase. Hasil penelitian menunjukan bahwa, ketuntasan belajar siswa pada siklus I sebesar 69,44\% dan pada siklus II sebesar 91,67\%. Dengan demikian ada peningkatan ketuntasan hasil belajar dari siklus I ke siklus II sebesar 22,23\%. Didapatkan juga bahwa pada siklus I jumlah kelompok yang tuntas sebesar $12,5 \%$ meningkat sebesar $50,0 \%$ menjadi $62,5 \%$ pada siklus kedua. Kesimpulan penelitian ini adalah bahwa penerapan model pembelajaran kooperatif tipe Student Team Achievement Divisions (STAD) dapat meningkatkan hasil belajar Fikih siswa kelas VII MTs Negeri Luwu Utara. Disarankan agar guru-guru mata pelajaran Fikih mempertimbangkan penggunaan model pembelajaran kooperatif tipe Student Team Achievement Divisions (STAD), dan juga disarankan ada penelitian lanjutan untuk melihat bagaimana hasil belajar siswa jika anggota kelompok tidak permanen.
\end{abstract}

Kata Kunci : Model Pembelajaran Kooperatif Tipe STAD, Peningkatan Hasil Belajar, Fikih

\section{ABSTRACT}

This research is motivated by the importance of teachers in choosing the right learning model, so that learning is as active as possible involving students, so students can build their own knowledge in a fun learning that leads to increased learning outcomes. The main objective of this research is to find out whether by applying the Student Team Achievement Divisions (STAD) cooperative learning model, it can improve the fiqh learning outcomes of seventh grade students of MTs Negeri Luwu Utara. This research was carried out in class VII MTs Negeri Luwu Utara starting in the second week of September until the first week of October 2020 (first semester). The number of students involved was 69 people, which were divided into 10 working groups. Observations were carried out in two cycles, where each cycle consisted of a preparation (planning) stage, action implementation, observation and evaluation, reflection, and action revision. Data analysis was carried out descriptively, by displaying it in the form of tables, histograms and equipped with percentage calculations. The results showed that student learning completeness in the first cycle was $69.44 \%$ and in the second cycle was $91.67 \%$. Thus, there is an increase in mastery learning outcomes from cycle I to cycle II by $22.23 \%$. It was also found that in the first cycle the number of groups who completed $12.5 \%$ increased by $50.0 \%$ to $62.5 \%$ in the second cycle. The conclusion of this study is that the application of the Student Team Achievement Divisions (STAD) type of cooperative learning model can improve 
Fiqh learning outcomes for seventh grade students of MTs Negeri Luwu Utara. It is recommended that Fiqh teachers consider the use of the Student Team Achievement Divisions (STAD) cooperative learning model, and it is also recommended that further research be conducted to see how student learning outcomes are if group members are not permanent.

Keywords: STAD Type Cooperative Learning Model, Improving Learning Outcomes, Fiqh

\section{PENDAHULUAN}

Pendekatan kontekstual (contextual teaching and learning) merupakan konsep belajar yang membantu guru mengaitkan antara materi yang diajarkan dengan situasi dunia nyata siswa dan mendorong siswa membuat hubungan antara pengetahuan yang dimilikinya dengan penerapannnya dalam kehidupan mereka sebagai anggota keluarga dan masyarakat. Tujuan bukan satu-satunya menjadi fokus perhatian, tetapi proses pembelajaran sangat penting diperhatikan.

Ketepatan memilih dan penggunaan model pembelajaran yang sesuai dengan siswa dalam materi yang akan diajarkan dapat membantu siswa dalam memahami materi pelajaran yang diajarkan. Salah satu diantaranya adalah model pembelajaran berkelompok dengan pendekatan STAD. Adapun kelebihan dari pendekatan STAD menurut Muhammad Noor (2000:17) antara lain:

1. Membantu mengembangkan tingkah laku dan hubungan yang lebih baik.

2. Memiliki tingkat berpikir yang lebih tinggi.

3. Materi yang dipelajari lebih mudah diingat dalam waktu yang lama.

4. Bermanfaat bagi siswa yang daya pikirnya rendah

5. Bertanggung jawab atas materi diskusi

6. Tidak ada diskriminasi dan inteligen.

7. Dapat diketahui kemampuan siswa dengan cepat.

8. Hasil belajar lebih tinggi

Sebagaimana data yang terdapat dilapangan menunjukan bahwa adanya peningkatan proses belajar siswa MTs Negeri Luwu Utara dengan menerapkan pembelajaran kooperatif dengan standar STAD. Pemilihan materi jurnal secara umum dan jurnal penyesuaian didasarkan pada pertimbangan bahwa untuk memahami materi ini dibutuhkan kemampuan analisa yang relatif tinggi, dan kemampuan matematis yang cukup. Berdasarkan uraian tersebut, penulis termotivasi untuk mengangkat permasalahan ini dalam Penelitian Tindakan kelas dengan judul "Penerapan Model Pembelajaran Koperatif Tipe STAD Untuk Meningkatkan Hasil Belajar Fikih siswa kelas VII MTs Negeri Luwu Utara".

Skor siswa dibandingkan dengan rata-rata skor yang lalu mereka sendiri, dan poin diberikan berdasarkan pada seberapa jauh siswa menyamai atau melampaui prestasinya yang lalu. Poin tiap anggota tim ini dijumlah untuk mendapatkan skor tim, dan tim yang mencapai kriteria tertentu dapat diberi sertifikat atau perhargaan yang lain. Penerapan teori ke dalam praktek, STAD sebuah metode pembelajaran kooperatif yang disebut Student Teams Achievement Division. STAD terdiri dari satu siklus pengajaran biasa, belajar kooperatif dalam tim dan kuis, dengan penghargaan atau ganjaran lain diberikan kepada tim yang anggotaanggotanya paling tinggi melampaui rekornya sendiri yang terdahulu.

Tercapainya tujuan pembelajaran tentu tidak semudah yang bagaimana kita pikirkan, tentunya peranan dan metode ataupun pendekatan yang dilakukan oleh seorang guru terhadap para siswa berperan penting. Mulyasa (2013:9) mengatakan bahwa " aspek, sikap, nilai, perasaan, motivasi, kepribadian, kebiasaan tidak akan mungkin dapat dihadirkan dalam sebuah pembelajaran kecuali kehadiran seorang guru"

Berhubung dengan hal tersebut, salah satu dari sekian banyaknya peranan seorang guru sebagi tenaga pendidik yaitu menjadi seorang motivator dalam sebuah pembelajaran. Musfah (2012:42) mengatakan bahwa "seorang guru harus bisa menjadi motivator bagi para siswa dan siswi sehingga hal tersebut dapat memberikan potensi kepada para murid untuk mengembangkan kemampuan yang dimiliki secara maksimal”. 


\section{METODE PENELITIAN}

Penelitian ini dilaksanakan di MTs Negeri Luwu Utara dalam semester I Tahun Pelajaran 2021/2022, selama 2 bulan yang dimulai pekan ke II bulan September sampai dengan pekan ke I bulan Oktober 2021. Subyek penelitian adalah siswa kelas VII MTs Negeri Luwu Utara Tahun Pelajaran 2021/2022, berjumlah 69 siswa terdiri dari 31 orang laki-laki dan 38 orang perempuan. Penelitian ini dilakukan dalam 2 siklus. Setiap siklus terdiri dari tahap persiapan, pelaksanaan tindakan, observasi, evaluasi, dan refleksi serta revisi tindakan. Adapun teknik pengumpulan data dalam metode penelitian ini, yaitu :

1). Lembar observasi yaitu untuk merekam pengisi proses belajar mengajar berlangsung berupa keberhasilan dan kelemahan tindakan yang diberikan.

2). Data tentang hasil belajar siswa diperoleh dari lembar evaluasi atau tes pada tiap akhir siklus.

Data yang terkumpul berupa data kuantitatif dianalisa dengan perhitungan prosentase yaitu: $P=f / n \times 100 \%$. Teknik ini digunakan untuk memperoleh gambaran umum mengenai perilaku siswa dalam kerja kelompok, efektifitas tindakan dan hambatan-hambatan yang dihadapi dalam pelaksanaan penelitian tindakan kelas. Prorgram excell digunakan untuk mengetahui koefisien determinasi korelasi nilai siswa pada siklus I dan nilai siswa pada siklus II.

\section{HASIL DAN PEMBAHASAN}

Student Teams Achievement Division (STAD) terdiri dari siklus kegiatan pengajaran biasa seperti berikut ini:

1. Mengajar; menyajikan pelajaran

2. Belajar dalam tim; siswa bekerja di dalam tim mereka dengan dipandu oleh lembar kegiatan siswa untuk menuntaskan materi pelajaran.

3. Tes; siswa mengerjakan kuis atau tugas lain secara individual

4. Penghargaan tim; skor tim dihitung berdasarkan skor anggota tim. Laporan berkala kelas atau papan pengumuman digunakan untuk memberi penghargaan kepada tim yang berhasil mencetak skor yang tinggi.

Langkah-langkah berikut ini menguraikan bagaimana mengantarkan siswa kepada Student Teams Achivement Division (STAD).

1. Membagi siswa ke dalam kelompok yang terdiri atas 4 atau 5 anggota.

2. Membuat Lembar Kegiatan Siswa (LKS) dan kuis pendek untuk pelajaran yang anda rencanakan untuk diajarkan.

3. Pada saat menjelaskan STAD, kepada kelas membacakan tugas-tugas yang harus dikerjakan oleh tim.

4. Bila tiba saatnya memberikan kuis, bagikan kuis atau bentuk evaluasi lain dan berikan waktu yang cukup kepada siswa untuk menyelesaikan tes itu.

5. Membuat skor individual skor tim.

Pengakuan kepada prestasi tim.

Perapkan model pembelajaran kooperatif tipe STAD dapat meningkatkan hasil belajar Fikih siswa kelas VII MTs Negeri Luwu Utara, manfaat yang diharapkan dari hasil penelitian ini, diantaranya, yaitu siswa akan dapat memberikan pengalaman baru dalam kegiatan pembelajaran Fikih untuk dapat meningkatkan hasil belajarnya, sebagai informasi bagi guru tentang alternatif model pembelajaran dalam meningkatkan kualitas hasil belajar Fikih, sebagai bahan referensi dan perbandingan bagi peneliti selanjutnya, dan terkhusus lagi bagi penulis, akan menambah pengalaman dalam menggunakan berbagai model pembelajaran.

Student Teams Achievement Division (STAD) yang dikembangkan oleh Robert Slavin dan teman-temannya di Universitas John Hopkin, dan merupakan pendekatan pembelajaran kooperatif yang paling sederhana. Guru menggunakan STAD, juga mengacu kepada belajar 
kelompok siswa, menyajikan informasi akademik baru kepada siswa setiap pekan menggunakan presentase verbal atau teks.

Dalam tipe STAD siswa dikelompokkan menjadi beberapa kelompok dengan anggota 4 - 5 orang, dan setiap kelompok haruslah heterogen. Guru menyajikan pelajaran, dan kemudian siswa bekerja di dalam tim mereka untuk memastikan bahwa seluruh anggota tim telah menguasai pelajaran tersebut. Akhirnya seluruh siswa dikenai kuis tentang materi itu, dan pada saat kuis ini mereka tidak boleh saling membantu.

\section{Hasil}

Setelah diadakan evaluasi, hasil belajar siswa untuk siklus I diperoleh data sebagai berikut

Tabel 1. Analisis Hasil Belajar Siswa pada Siklus I

\begin{tabular}{|c|c|c|c|c|}
\hline \multirow{2}{*}{ No } & \multirow{2}{*}{ Kelompok } & \multirow{2}{*}{$\begin{array}{c}\text { Anggota } \\
\text { kelompok }\end{array}$} & \multicolumn{2}{|c|}{$\begin{array}{c}\text { Anggota Kelompok Yang } \\
\text { Tuntas/Tidak Tuntas }\end{array}$} \\
\cline { 3 - 5 } & & Tuntas & Tidak Tuntas \\
\hline 1 & I & 5 Orang & 3 Orang & 2 Orang \\
\hline 2 & II & 5 Orang & 4 Orang & 1 Orang \\
\hline 3 & III & 5 Orang & 4 Orang & 1 Orang \\
\hline 4 & IV & 4 Orang & 3 Orang & 2 Orang \\
\hline 5 & V & 4 Orang & 3 Orang & 2 Orang \\
\hline 6 & VI & 4 Orang & 2 Orang & 2 Orang \\
\hline 7 & VII & 4 Orang & 4 Orang & 0 Orang \\
\hline 8 & VIII & 36 Orang & 20 Orang & 13 Orang \\
\hline & Jumlah & $100 \%$ & $69,44 \%$ & $30,56 \%$ \\
\hline
\end{tabular}

Berdasarkan data di atas dapat disimpulkan bahwa dalam siklus I secara klasikal siswa yang sudah tuntas dalam belajar mencapai $69,44 \%$ sedangkan siswa yang belum tuntas mencapai 30,56\% (data nilai terlampir). Menurut ketentuan kurikulum 2013, ketuntasan belajar secara klasikal harus mencapai $100 \%$. Kepada siswa yang belum tuntas diberikan perbaikan (remedial). Dari data pada tabel di atas juga nampak bahwa hanya satu kelompok (12,5\%), yaitu kelompok VIII yang tuntas belajar seluruh anggotanya.

Dari uraian di atas dapat disimpulkan bahwa harapan dari pembelajaran kooperatif tipe STAD untuk meningkatkan hasil belajar siswa baik secara individu maupun kelompok belum berhasil. Pada siklus II perlu pemantapan langkah-langkah kooperatif tipe STAD.

Setelah diadakan tes pada siklus II untuk mengetahui hasil belajar siswa maka diperoleh data sebagai berikut :

Tabel 2. Analisis Hasil Belajar Siswa pada Siklus II

\begin{tabular}{|c|c|c|c|c|}
\hline \multirow{2}{*}{ No. } & \multirow{2}{*}{ Kelompok } & \multirow{2}{*}{$\begin{array}{c}\text { Anggota } \\
\text { Kelompok }\end{array}$} & \multicolumn{2}{|c|}{$\begin{array}{c}\text { Anggota Kelompok yang } \\
\text { Tuntas/Tidak Tuntas }\end{array}$} \\
\cline { 4 - 5 } & & & Tuntas & Tidak Tuntas \\
\hline 1 & 1 & 5 Orang & 4 Orang & 1 Orang \\
\hline 2 & 2 & 5 Orang & 5 Orang & - \\
\hline 3 & 3 & 5 Orang & 5 Orang & - \\
\hline 4 & 4 & 5 Orang & 4 Orang & 1 orang \\
\hline 5 & 5 & 4 Orang & 4 Orang & - \\
\hline 6 & 6 & 4 Orang & 4 Orang & - \\
\hline 7 & 7 & 4 Orang & 3 Orang & 1 orang \\
\hline 8 & 8 & 4 Orang & 4 Orang & - \\
\hline \multicolumn{2}{|c|}{ Jumlah } & 36 orang & 33 orang & 3 Orang \\
\hline
\end{tabular}




\begin{tabular}{|c|c|c|c|}
\hline Persentase & $100 \%$ & $91,67 \%$ & $8,33 \%$ \\
\hline
\end{tabular}

Dari tabel di atas dapat disimpulkan, pada siklus II ini hasil belajar (ketuntasan belajar) meningkat dari 69,44\% menjadi 91,67\% (data nilai terlampir). Dari analisis hasil belajar di atas, ternyata tindakan yang dilakukan pada siklus II mulai terlaksana dengan baik.

Pada akhir siklus II, tergambar pada tabel 4.6. bahwa walaupun ketuntasan belajar sudah meningkat dari $69,44 \%$ menjadi $91,67 \%$ pada siklus II, namun belum memenuhi tuntutan kurikulum 2013 yang menginginkan ketuntasan belajar 100\%.

Koefisien korelasi antara hasil belajar siswa pada siklus I dengan siklus II dengan menggunakan program excell sebesar $r=0,83$. Nilai koefisien korelasi yang tinggi ini memberikan informasi bahwa siswa yang memiliki hasil belajar yang baik pada siklus I semakin baik pada siklus kedua. Demikian juga siswa yang hasil belajarnya memang rendah juga rendah pada siklus kedua. Ini berarti bahwa pada beberapa siswa yang tetap tidak tuntas belajarnya (3 orang) perlu dilakukan penyelidikan lebih seksama penyebab ketidak-tuntasan belajarnya.

Adapun hasil belajar tiap kelompok pada setiap siklus disajikan pada tabel berikut.

Tabel 3. Perbandingan Ketuntasan Belajar Tiap Kelompok pada Setiap Siklus

\begin{tabular}{|c|c|c|}
\hline \multirow{2}{*}{ Kelompok } & \multicolumn{2}{|c|}{ Ketuntasan pada } \\
\cline { 2 - 3 } & Siklus I & Siklus II \\
\hline I & $60 \%$ & $80 \%$ \\
\hline II & $80 \%$ & $100 \%$ \\
\hline III & $80 \%$ & $100 \%$ \\
\hline IV & $60 \%$ & $80 \%$ \\
\hline V & $50 \%$ & $100 \%$ \\
\hline VI & $75 \%$ & $100 \%$ \\
\hline VII & $50 \%$ & $75 \%$ \\
\hline VIII & $100 \%$ & $100 \%$ \\
\hline
\end{tabular}

Adapun grafik presentase peningkatan hasil belajar siswa MTs Negeri Luwu Utara kelas VII pada mata pelajarn fikih, melalui model pembelajaran tipe STAD, yaitu
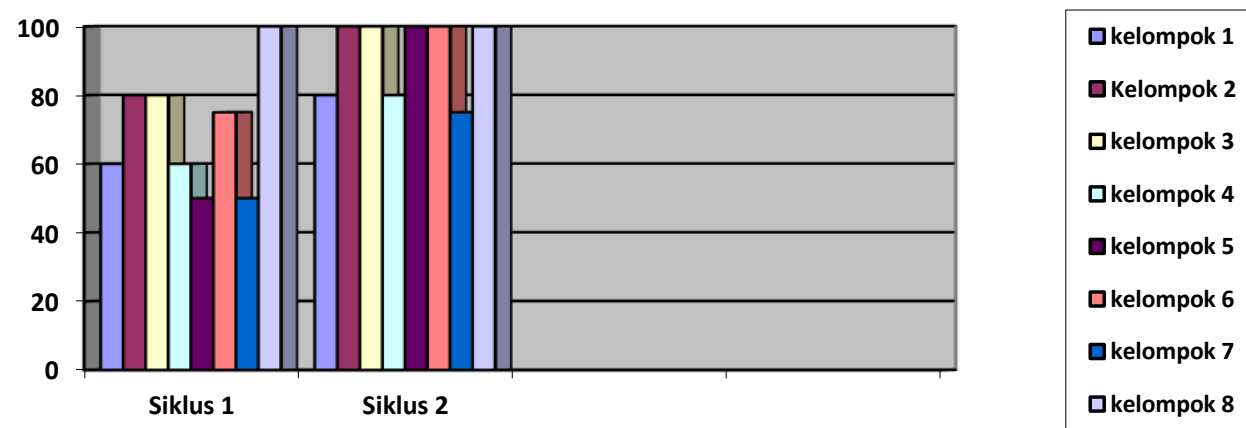

Gambar 1. Grafik presentase peningkatan hasil belajar siswa

Dari Tabel dan grafik di atas nampak dengan jelas bahwa ketuntasan belajar kelompok juga mengalami peningkatan sangat signifikan (dari 1 kelompok pada siklus I menjadi 7 kelompok pada siklus II).

Dari hasil analisis belajar siswa ada siklus I dan siklus II di atas jelas menunjukan bahwa adanya peningkatan hasil belajar tersebut, maka penerapan model pembelajaran Kooperatif Tipe STAD ini dapat meningkatkan hasil belajar Pendidikan Fikih walaupun belum menunjukan hasil yang sangat optimal.

\section{Pembahasan}


Menurut Sardiman A.M (2001:53), belajar adalah proses dimana suatu aktivitas mengalami perubahan melalui interaksi dengan alam lingkungannya. Pendapat tersebut didukung pula oleh Milton dan Mom, belajar adalah suatu perubahan dalam pengalaman atau tingkah laku sebagai hasil dari observasi yang bertujuan aktivitas penuh, pikiran penuh yang disebut reaksi-reaksi emosi yang penuh motivasi dimana hasil perubahan itu lebih memuaskan (Soli Abimayu, 1980:47).

Dari pendapat di atas, maka dapat disimpulkan bahwa di dalam proses belajar mengajar diharapkan adanya perubahan yang positif dimana perubahan ini diperoleh dari hasil interaksi dengan lingkungan sekitarnya. Untuk mengetahui hasil belajar siswa, maka dilakukan evaluasi. Evaluasi dilakukan terus-menerus dan dilakukan untuk menentukan keberhasilan belajar. Yang paling penting adalah sebagai dasar untuk umpan balik dari proses belajar mengajar yang dilaksanakan.

Penilaian hasil belajar dapat berupa tes. Kedudukan tes dalam proses penilaian adalah salah satu teknik penilaian yang termasuk dalam pengukuran. Brown F.G menyatakan bahwa "suatu tes dapat didefinisikan sebagai prosedur yang sistematis untuk mengukur suatu sampel dari suatu perilaku individu" (Mudjijo, 1995:28).

Tes hasil belajar terdiri atas sejumlah soal-soal yang memiliki tingkat kesukaran tertentu, ada yang mudah, sedang dan sukar. Pada siswa diberi kesempatan untuk menyelesaikan semua persoalan yang ada dalam waktu yang telah ditentukan. Oleh karena itu, tes hasil belajar lebih merupakan tes kekuatan daripada tes kecepatan. Untuk lebih jelasnya, kita simak penjelasan Anastasi, A. sebagai berikut:

"Tes hasil belajar itu merupakan salah satu jenis tes kekuatan yang bermaksud mengukur kemampuan siswa yang di tes dalam menjawab atau memecahkan persoalan sehubungan dengan hal-hal atau materi pelajaran yang dipelajarinya. Dengan kata lain, tes hasil belajar bermaksud mengukur sejauh mana para siswa telah menguasai atau mencapai tujuan-tujuan pengajaran yang telah ditetapkan" (Mudjijo, 1995:29).

Berdasarkan uraian di atas, maka yang dimaksud hasil belajar Pendidikan Fikih dalam penelitian tindakan kelas ini adalah skor yang dicapai oleh siswa dalam mengikuti proses belajar mengajar sesuai dengan tujuan yang akan dicapai.

\section{KESIMPULAN}

Dari hasil penelitian terbukti bahwa penerapan model pembelajaran kooperatif tipe STAD dapat meningkatkan hasil belajar Pendidikan Fikih siswa kelas VII MTs Negeri Luwu Utara Tahun Pelajaran 2021/2022. Meningkatnya hasil belajar ini merupakan dampak positif dari proses pembelajaran dengan menerapkan model pembelajaran kooperatif tipe STAD kepada siswa. Hal ini disebabkan karena setiap siswa diminta mempertanggungjawabkan secara individu materi yang ditangani dalam mengajar kelompok secara kooperatif yang mengacu pada metode pembelajaran dimana siswa bekerja sama dalam kelompok kecil saling membantu dalam belajar. Mereka terbiasa dilatih keterampilan khusus untuk membantu mereka bekerja sama dengan baik, mengajukan pertanyaan dengan benar, dan sebagainya.

Terjadinya peningkatan kelompok yang tuntas belajarnya dari siklus I dibandingkan dengan siklus II juga mengindikasikan bahwa pembelajaran kooperatif ini mampu membantu para anggota kelompok untuk bersama-sama dengan teman kelompoknya meraih kesuksesan belajar bersama. Dengan kata lain siswa mendapat kesempatam bekerja sama untuk memastikan bahwa seluruh anggota kelompok telah menguasai segala sesuatu tentang pelajaran tersebut dalam persiapan untuk mengerjakan tes, bekerja dalam suatu format belajar kelompok dan kelompok kooperatif dapat digunakan untuk memecahkan sebuah masalah kompleks.

Keberhasilan penerapan model pembelajaran kooperatif tipe STAD tidak hanya mampu meningkatkan kemampuan siswa dalam bekerja sama, tetapi juga mampu melibatkan sosiemosional siswa, melatih siswa bekerja disiplin dan tepat waktu serta dapat melatih siswa dalam kepemimpinan. 
Berdasarkan uraian di atas, penulis semakin yakin bahwa hasil pencapaian skor siswa yang diajar dengan model pembelajaran kooperatif Tipe STAD menunjukkan keberhasilan siswa dengan metode ini. Dengan demikian salah satu upaya yang dapat dilakukan untuk meningkatkan hasil belajar adalah dengan menerapkan model pembelajaran kooperatif tipe STAD, khususnya pada siswa kelas VII MTs Negeri Luwu Utara.

\section{DAFTAR PUSTAKA}

Arikunto, Suharsimi, (1998). Dasar-dasar Evaluasi Pendidikan :Jakarta: Bumi Aksara

Departemen Pendidikan Nasioal, (2005).Ilmu Pengetahuan Sosial:Materi Pelatihan Terintegrasi :Jakarta:Kegiatan Pengembangan Sistem dan Pengendalian Program SLTP.

Firdaus, Yogi dkk. (2000). Pelajaran Pendidikan Fikih SMU I : Jakarta:Erlangga

Ibrahim Muslimin, dkk, (2000). Pembelajaran Kooperatif: Unversitas Negeri Surabaya.

Johnson. (1991). Pembelajaran Kooperatif : Universitas Surabaya.

Lundgren. (1994).Pembelajaran Kooperatif: Universitas Surabaya

Mudjijo. (1995).Tes Hasil Belajar : Jakarta Bumi Aksara.

Noor.,Muhammad. (2000). Pembelajaran Kooperatif : Univeritas Negeri Surabaya.

Purwanto.,M.Ngalim.(1990). Prinsip-Prinsip dan Teknik Evaluasi Pengajaran : Bandung:Remaja Rosda Karya

Richard,(1993).Pembelajan Kooperatf : Universitas Negeri Surabaya.

Sardiman., A.M. (1992).Interaksi dan Motivasi Belajar Mengajar:Jakarta:Rajawali Press

Slameto, (1995). Belajar dan Faktor-Faktor yang Mempengaruhiya:Jakarta:Bumi Aksara.

Soemarso, SR, 1991. Pendidikan Fikih suatu pengantar: Jakarta: Lembaga Penerbit FEUI.

Soli., Abimayu. (1997). Diagnostik Kesulitan Belajar:Ujung Pandang: FIP IKIP Ujung Pandang

Sudjana.(1992). Metode Statistika:Bandung:Tarsito

Sumanto. (1992).Metodologi Penelitian Sosial dan Pendidikan:Yogyakarta: Andi Offset 